Chirurgia (2017) 112: 130-135

No. 2, March - April

Copyright@ Celsius

http://dx.doi.org/10.21614/chirurgia.112.2.130

\title{
Urgent Organ Retrieval from Non-Heart-Beating Donor with Declared Brain Death: Harvest at Arrest
}

\author{
Ihsan Yıldız, Yavuz Savaș Koca, Mehmet Zafer Sabuncuoglu \\ Department of General Surgery, Suleyman Demirel University, Çünür, Isparta, Turkey
}

Corresponding author:

Ihsan Yıldiz, MD

Suleyman Demirel UniversityÇünür,

32260, Isparta, Turkey

E-mail: drihsanyildiz@gmail.com

Abbreviation:

NHBD: Non-heart-beating donör

Received: 24.11.2017

Accepted: 1.03.2017

\section{Rezumat}

Prelevarea de urgență de organe de la donatori în moarte cerebrală după oprire cardiacă: prelevarea în stop cardiac

Scop: Din cauza numărului insuficient de donatori disponibili pentru a acoperi nevoia de transplanturi de organe, noi cercetări sunt în desfăşurare. În contextul acesta, cazurile de stop cardiac şi moarte cerebrală au fost evaluate ca donatori probabili în cursul ultimilor ani. Scopul acestui studiu este de a discuta tehnicile salutare de prelevare de organe cu distrugere minimă a tesutului şi rapiditate maximă de efectuare, în condițile asigurate de centrul nostru, precum şi experiența proprie în acest domeniu.

Materiale şi metode: Un număr total de 4 din 13 pacienți aflați în moarte cerebrală care au prezentat stop cardiac în aşteptarea rezultatelor de laborator în cadrul centrului nostru în perioada 2015-2016 au fost conduşi către sala de operație de urgență sub masaj cardiac şi s-a efectuat prelevare de organe în regim de urgență. Datele clinice ale acestui grup specific au fost analizate. Rezultate: In perioada 2015-2016 au existat 13 cazuri de prelevare de organe de la pacienți aflați în moarte cerebrală. Din aceste 13 cazuri, 9 au fost supuse laparotomiei şi canulării de urgență, iar organele au fost prelevate după perfuzia cu soluție rece in situ, fără alte complicații. În schimb, în 4 cazuri care au prezentat stop cardiac la care s-a efectuat perfuzie cu soluții reci ex-vivo din lipsa de mijloace în sala de operație, afectarea vasculară şi parenchimală au apărut la nivelul a două organe hepatice şi a 2 rinichi. Utilizând această tehnică au fost prelevate şi transplantate 4 ficati şi 8 rinichi.

Concluzii: Laparotomia de urgență, canularea şi perfuzia cu soluții saline reci in situ reprezintă abordarea ideală pentru un timp de 
ischemie la cald mai scurt şi un grad redus de afectare a organelor provenite de la donatori în condiții dificile precum stopul cardiac în spital, dar tehnica perfuzării cu soluții reci ex-vivo trebuie avută în vedere pentru a acoperi nevoia tot mai mare de organe pentru transplant.

Cuvinte cheie: transplant, transplant renal, prelevare de organe, donator după oprire cardiacă

\section{Abstract}

Objective: Due to insufficient donor number to meet the needs of organ transplantation, new researches are ongoing. In this context, the cases with cardiac arrest and brain dead are assessed as probable donors in recent years. The aim of this study is to discuss the healthfully techniques of organs retrieval with minimum damage and maximum rapidity in conditions of our center and to present our own experiences.

Material and Method: A total 4 of 13 patients brain dead declared and developed cardiac arrest while awaiting for laboratory test results in our center between 2015 and 2016, were urgently taken into operation under external heart massage and urgent organ retrieval were performed. The clinical data of this specific group were analyzed.

Results: Thirteen donors with brain dead organ procurement were performed in our center between 2015 and 2016. Of the 13 cases, 9 had undergone urgent laparotomy and cannulation, and the organs were retrieved after in-situ cold perfusion and no problems occurred in these cases. However, in 4 cases who developed cardiac arrest ex-vivo cold perfusion was performed due to lack of facilities in operation room,vascular and paranchimal damage occurred in 2 livers and the 2 kidneys. With this technique, four liver and eight kidneys were removed and transplanted.

Conclusion: Urgent laparotomy, cannulation, and in-situ cold perfusion is ideal approach for shorter warm ischemia time and less organ damage in cadavers in difficult conditions such as sudden cardiac arrest in hospital, however ex-vivo cold perfusion technique should be kept in mind to meet the increasing of more and more organ needs.

Key words: transplantation, kidney transplantation, organ procurement, non-heart-beating-donor

\section{Introduction}

The current treatment of end-stage renal failure is renal transplantation. However, the demand can not be meet due to the multitude of patient list waiting for organ. Actually, nonheart-beating donors (NHBD) are known as an option for organ donors such as pancreas, liver and kidney (1). This cases are classified by the Maastricht system (2). These criteria were afterwards modified as category 1:dead on arrival; category 2: unsuccessful resuscitation; category 3: awaiting cardiac arrest; category 4: cardiac arrest after brain-stem death donor; category V: unexpected cardiac arrest in a critically ill patient. Category V was added in 2000 to this classification (3). In this system category III is classified uncontrolled and I, II, IV and V are uncontrolled (Table 1). Therefore, cases with cardiac arrest and brain death NHBDs assessed as category 3 and 4 possible donors according to Maastricht criteria.

However, medico-legal and ethical concerns are available on NHBDs. Furthermore, an urgent organ retrieval is of great importance to protect the organs and minimize the warm ischemia time. Several surgical methods were suggested for this issue (4-8).

This study aims to discuss the techniques to 
Table 1. NHBDs are grouped by the Maastricht classification

\begin{tabular}{lll}
\hline I & Brought in dead & Uncontrolled \\
\hline II & Unsuccessful resuscitation & Uncontrolled \\
\hline III & Awaiting cardiac arrest & Controlled \\
\hline IV & Cardiac arrest after brain-stem death & Controlled \\
\hline V & Cardiac arrest in a hospital inpatient & Uncontrolled \\
& & (added in 2000) \\
\hline
\end{tabular}

retrieve organs healthfully with minimum damage and maximum speed in conditions of our hospital, and to present our own experiences.

\section{Material and Method}

Urgent organ retrieval was performed on a total of 13 patients with declared brain death. Four cases developed cardiac arrest while awaiting for laboratory test results with 4 points from Maastricht criteria in Süleyman Demirel University Faculty of Medicine, Organ Transplantation Centre, between 2015-2016. The essential treatments included cardiotonics (dopamine $5 \mathrm{mcg} / \mathrm{kg} / \mathrm{min}$ ), heparin (5000-10000 $\mathrm{U})$, corticosteroid $(50 \mathrm{mg}$ ) and 1 ampoule of furosemide. Nine cases were urgently taken into operation with normal conditions. After urgent median laparotomy, the abdominal aorta was clamped below the diaphragm, and cannulated at the level $2-3 \mathrm{~cm}$ over the bifurcatio below the inferior mesenteric artery using no: 28 thorax tube. The portal vein was cannulated via the inferior mesenteric vein with no:8-10 feeding tube. After the abdomen was cooled with sludgeice, cold perfusion taps were opened from inferior mesenteric artery with $3000 \mathrm{ml}$ ringer lactate and aortic cannula with $3000 \mathrm{ml}$ Custodiol-HTK (histidine-tryptophan-ketoglutarate) or Viaspan (Bristol-Myers Squibb Pharmaceutical Limited). The vena cava was opened and washing was performed. After, in situ cooling the organ retrieval was performed on 9 cases. In 4 cases who had cardiac arrest taken to the operation under cardiac massage and then the urgent organ retrieval followed by ex-vivo cooling at backtable.

\section{Results}

Brain-dead cases with mean age of 36 (interquartile range, 26-58) whose family consents were obtained for organ donation were followed by the same anesthesia staff in intensive care units. The average length of stay in intensive care unit was 3.6 (2-7) days. The causes of brain death were intracranial haemorrhage $(\mathrm{ICH})(\mathrm{no}=6)$ and cerebral contusion $(n o=1)$ due to trauma and ICH $(n o=6)$ due to other cerebrovascular disease. None of braindead donors had circumstances which constitute obstacle for organ use such as previous organ insufficiency, organ damage, sepsis, selfsuicide, and AIDS. All of cases who were performed urgent organ retrieval were which controlled condition of Maastricht Category 4 (developing arrest while awaiting). The average kidney donor risk index (KDRI) and (KDPI) of the cases were $0.9452(0.854-1.161) 45 \%$ (35$65 \%)$ respectively.

Organ retrieval with in-situ cold perfusion under normal conditions was performed on 9 of total 13 cases whose laboratory results were being awaited. Vascular or organ damage and organ non-function did not occured in these cases. The other cases mean age of NHBDs $(n=4)$ was 39 (iqr, 26-50). Since these cases had cardiac arrest for once (1 patient), twice (2 patient), and three times (1 patient), and could not be resuscitated and NHBDs were urgently taken into operation. In order to protect organs from warm ischemia, organs were urgently retrieved cooling the abdomen without vascular cannulation. Although cold perfusion at backtable was performed afterwards, paranchimal and hepatic arterial damage of 2 livers including vascular shortness right renal vein, and left renal artery occurred in 2 patients, respectively. Warm ischemia time of the 4 cases was aslo longer than other cases owing to the rush and technical difficulties. The warm ischemia time was averagely 11 minutes (interquartile range; 6-15) for 9 cases and 20 minutes (interquartile range, 15-25) for 4 NHBDs who had cardiac arrest.

Two of 4 liver worked ssuccesfully. One liver could not be transplanted due to hepatic 
Table 2. Oneyear's NHBD experience of ourcenter

\begin{tabular}{|c|c|c|c|c|c|c|c|}
\hline $\begin{array}{l}\text { Number } \\
\text { of cases }\end{array}$ & Meanage & $\begin{array}{l}\text { Removed } \\
\text { Liver }\end{array}$ & $\begin{array}{l}\text { Removed } \\
\text { Kidneys }\end{array}$ & $\begin{array}{l}\text { Category of } \\
\text { the NHBDs }\end{array}$ & Techniques & $\begin{array}{l}\text { Vascular } \\
\text { damage types } \\
\text { in NHBDs }\end{array}$ & $\begin{array}{l}\text { Mean warm } \\
\text { ischemia time } \\
\text { (minutes) }\end{array}$ \\
\hline 4 & $\begin{array}{l}39 \\
\text { (iqr, 26-50) }\end{array}$ & $\begin{array}{l}\text { Four livers were } \\
\text { removed. } \\
\text { Two livers worked } \\
\text { succesfully and } 1 \text { was } \\
\text { primary non-function } \\
\text { due to warm ischemic } \\
\text { paranchimal damage. } \\
1 \text { could not be transplanted } \\
\text { due hapatic arter damage }\end{array}$ & $\begin{array}{l}8 \text { kidneys } \\
\text { transplanted. } \\
2 \text { were } \\
\text { non-function. } \\
\text { Six of them } \\
\text { worked. }\end{array}$ & $\begin{array}{l}\text { Maastricht } 4 \\
\text { (controlled) }\end{array}$ & $\begin{array}{l}\text { ex-vivo cold } \\
\text { perfusion } \\
\text { (NHBDs) }\end{array}$ & $\begin{array}{l}1 \text { damage of } \\
\text { hepatic artery } \\
2 \text { right renal vein } \\
(\mathrm{no}=1) \text {, and left } \\
\text { renal artery }(\mathrm{n} 0=1)\end{array}$ & $\begin{array}{l}20 \text { (iqr; 15-25) } \\
\text { forex-vivo }\end{array}$ \\
\hline
\end{tabular}

Iqr: interquartilerangeNHBD: non-heart-beatingdonor

arter injury and primary non-function was diagnosed in one cases becasuse of paranchymal damage of warm ischemia. Eight kidneys were transplanted and 6 of them worked without any problem. (Table 2)

Arteries injured and parenchyma-damaged livers did not work. There was no difference in complications between the HBD and NHBD recipients, and there was no difference in functioning of the working livers.

Synthetic vascular grafts were used due to shortness of right and left renal artey and renal vein in two cases. However, two primary nonfunction cases had early graft nephrectomy.

\section{Discussion}

The most important obstance against organ transplantation is insufficient organ donation. Due to increasing human population, developed technology and prolonged human life the need for transplantation increases over the years. In Turkey, the number of patients who died while waiting transplantation recorded as 1698, 523 and 183 for kidney, liver and heart, respectively in 2015 (Fig. 1). Different researches are ongoing to meet the need of organs for transplantation. The use of organs from cadavers with cardiac arrest (NHBD) to cope with this

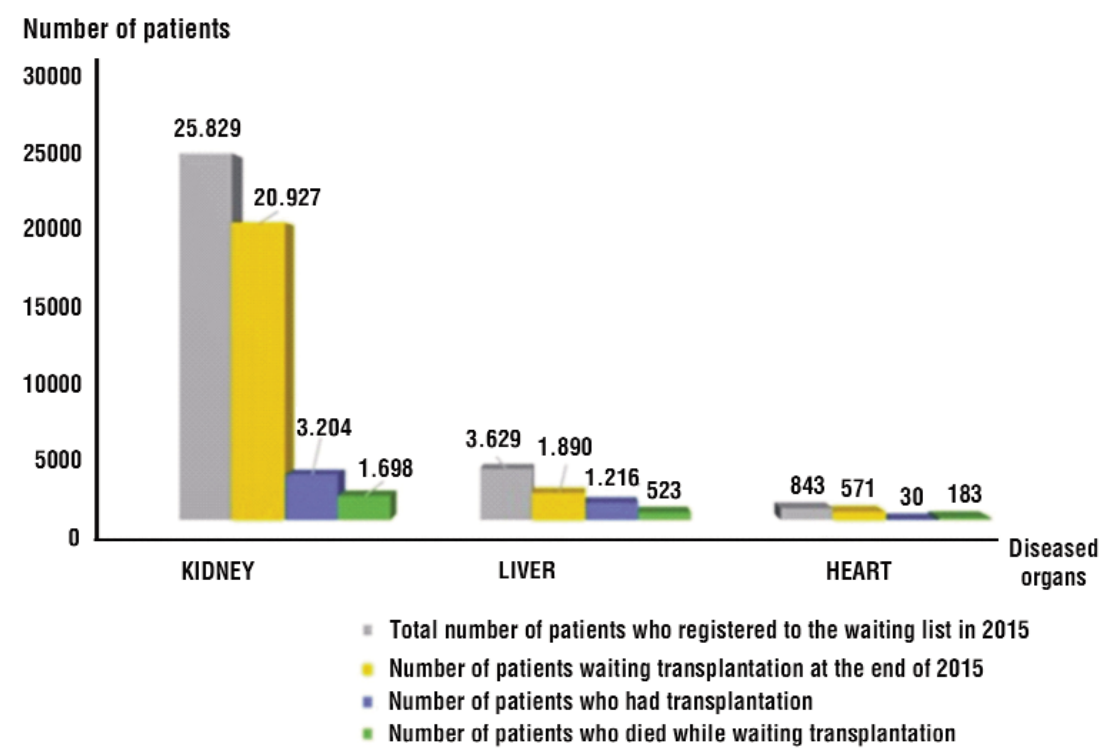

Figure 1. Features of registered waiting list, organ transplanted patients, in 2015 (Turkey) 
obstacle is equivocal. Based on the constraint in organ procurement, organ harvest from NHBD has come to the fore several times since the brain death declaration criteria was published in Harvard Medical School in $1986(7,8)$. To elucidate the condition in detail, Maastricht (1-4) and Modified Maastricht criteria (1-5) were published (8). All of our cases were category 4, awaiting cardiac arrest.

The average kidney donor risk index (KDRI) and (KDPI) of the cases were 0.9452 (0.854-1.161) 45\% (35-65\%) respectively. However, these rates were not calculated in the cases that were not organ transplanted.

Nowadays while organ retrieval from NHBD is not approved in some countries including Germany, there are countries performing organ procurement from NHBD including America and Canada (7). There is not a certain decision on this issue in our country. Increased rate of renal failure and difficulties in organ procurement remain a substantial problem in our country. According to data of the Turkish Ministry of Health, the number of people with renal diseases is about 60000, increasing day by day, and the requirement can not be met by current rate of organ donation (web: https://organ.saglik.gov.tr). In-situ or ex-vivo cold perfusion may be performed at NHBD organ procurement. To shorten the warm ischemia time is important to protect graft functions. Although there are some written rules, different conditions may emerge in different circumstances $(5,9,10)$. Some institutions have composed protocols for several surgical techniques and perfusion solutions for ex-vivo and in-vivo cold perfusion methods $(5,9,11)$. We used ringer lactate for washing organs and Custodiol-HTK (histidintryptophan-ketoglutarate) or Viaspan solutions (Bristol-Myers Squibb Pharmaceutical Limited) for organ preservation. Although there are authors recommending femoral artery and vein catheterization, we did not use this method due to inconvenience of surgical technical conditions. We performed organ retrieval following many organ donations in our newlyestablished organ transplantation centre. A total of 13 cadavers were saved in a year. The organs were attemted to retrieve without damage. However, urgent operation was performed in 4 of 9 cases due to NHBD status and some undesired results such as vascular injury and long warm ischemia time occurred.

As we mentioned before there was no difference in complications between the HBD and NHBD recipients, and there was no difference in functioning of the working livers. In our study, we wanted to draw attention to surgical injuries during surgery. We perceive the main reason is cardiac arrest due to intensive care problems in cadaver follow-up and the second reason is the rush and technical difficulties in surgery. We consider that we can surpass these difficulties with the experience we gain in time. The most challenging obstacle against organ transplantation is insufficient organ donation. The use of organs from cadavers with cardiac arrest to cope with this obstacle is under debate. In such a situation minimizing the warm ischemia time becomes prominent in order to protect the graft functions. While there are some rules in this issue, different conditions may require different practices such as ex-vivo and in-situ perfusion methods. The most important way to reduction of warm ischemic time is after a successful resuscitation then using urgent midline-transvers incision laparotomy to reach the organs and removing them.

NHBDs are utilized for expanding the organ pool for organ transplantation. Although the most convenient method in NHBD procurement is in-situ cold perfusion to retrieve organs without injury in the shortest time and to reduce warm ischemia time, ex-vivo perfusion should be kept in mind in difficult conditions.

\section{Conflicts of interest}

There are no conflicts of interest between authors.

\section{Acknowledgement}

This article was accepted as a poster presentation in Tx-2016 Congress (The $11^{\text {th }}$ Congress of the Turkish Transplant Centers Coordination 
Association (TTCCA 2016) October (12-15) 2016 in Konya, Turkey) with poster number: (P108) 1033.

\section{References}

1. Dornbierer M, Stadelmann M, Sourdon J, Gahl B, Cook S, Carrel TP, et al. Early reperfusion hemodynamics predict recovery in rat hearts: a potential approach towards evaluating cardiac grafts from nonheart-beating donors. PLoS One. 2012;7(8):e43642. doi: 10.1371/ journal.pone.0043642. Epub 2012 Aug 21.

2. Kootstra G, Daemen JH, Oomen AP. Categories of non-heart-beating donors. Transplant Proc. 1995;27(5):2893-4.

3. Sánchez-Fructuoso Al, Prats D, Torrente J, Pérez-Contín MJ, Fernández C, Alvarez J, et al. Renal transplantation from non-heart beating donors: a promising alternative to enlarge the donor pool. J Am Soc Nephrol. 2000;11(2):350-8.

4. Martin-Villen L, Revuelto-Rey J, Aldabo-Pallas T, Correa-Chamorro E, Gallego-Corpa A, Ruiz Del Portal-Ruiz Granados P, et al. Non-heartbeating donor program: results after 3 years of experience. Transplant Proc. 2015;47(9):2567-9. doi: 10.1016/j.transproceed.2015.09.050.
5. Khodeli N, Chkhaidze Z, Partsakhashvili D, Pilishvili O, Kordzaia D. Theoretical background of finding organs for transplantation among non-heart beating donors under unsuccessful extracorporeal resuscitation (Literature Review). Georgian Med News. 2016;(254):92-7. Russian

6. Choong JW, Ou R, Lim YW, Rosenfeldt FL. Cold crystalloid perfusion provides cardiac preservation superior to cold storage for donation after circulatory death. Transplantation. 2016;100(3):546-53. doi: 10.1097/TP.0000000000000926.

7. Heide W. Non-heart-beating donors are ineligible. Nervenarzt. 2016; 87(2):161-8. doi: 10.1007/s00115-015-0048-y. German

8. Shimizu K, Miyagi S, Miyazawa K, Maida K, Kashiwadate T, Hara Y, et al. Resveratrol Prevents Warm Ischemia-Reperfusion Injury in Liver Grafts From Non-Heart-Beating Donor Rats. Transplant Proc. 2016;48(4):1221-5. doi: 10.1016/j.transproceed.2015.11.031.

9. Ridley S, Bonner S, Bray K, Falvey S, Mackay J, Manara A. UK guidance for non-heart-beating donation. Br J Anaesth. 2005; 95(5):592-5. Epub 2005 Sep 23.

10. Kootstra G, van Heurn E. Non-heartbeating donation of kidneys for transplantation. Nat Clin Pract Nephrol. 2007;3(3):154-63.

11. Wunderlich H. Diagnostic workup of brain-dead organ donors and organ retrieval. Urologe A. 2015;54(10):1362-7. doi: 10.1007/s00120015-3905-1. German 